\title{
ЕКОНОМІЧНИЙ ВЕКТОР СУЧАСНОЇ ДЕЦЕНТРАЛІЗАЦІї: ПРОБЛЕМИ ТА ШЛЯХИ ВИРІШЕННЯ
}

\section{ECONOMIC VECTOR OF MODERN DECENTRALIZATION: PROBLEMS AND WAYS OF SOLUTION}

\author{
Бородіна Оксана Анатоліївна \\ кандидат наук з державного управління, докторантка, \\ Інститут економіки промисловості \\ Національної академії наук України \\ ORCID: https://orcid.org/0000-0001-7469-9529
}

\author{
Borodina Oksana \\ Institute of Industrial Economics of the \\ National Academy of Sciences of Ukraine
}

\begin{abstract}
У статті проведено аналіз сучасного етапу ресрорми децентралізації. Наголошено невідворотність та фунндаментальний характер змін, можливість та доцільність нестандартних рішень 3 метою реформування економічної системи. Аналіз стану реформи проведено у трьох площинах: політичній, земельній, соціальній. Виявлено перелік проблем, притаманних сучасному етапу реформування в усіх аспектах проведення дослідження, надано дієвих рекомендацій щодо необхідного конституційного та законодавчого врегулювання, створення відповідних регуляторних органів, упорядкування процесу фінансування місцевих громад, внесення змін до Бюджетного та Податкового кодексів. Окремого розгляду набули економічні питання земельного реформування. Констатовано необхідність фундаментальних змін у підходах до кадастрового обліку земель, прийняття Закону про реституцію за прикладом держав, що мали такі ж умови розвитку.
\end{abstract}

Ключові слова: децентралізація, адміністративно-територіальна реформа, модернізація економіки, земельна ресорма.

В статье проведен анализ современного этапа реформы децентрализации. Отмечается возможность и целесообразность нестандартных решений для реформирования экономики. Анализ ресрормы проведены в трех плоскостях: политической, земельной, социальной. Выявлен перечень проблем, присущих современному этапу реформирования во всех аспектах проведения исследования, предоставлено действенных рекомендаций по необходимому конституционного и законодательного урегулирования, создание соответствующих регуляторных органов, упорядочение процесса финансирования местных общин, внесение изменений в Бюджетный и Налоговый кодексы. Отдельно рассматриваются экономические вопросы земельной реформы. Констатирована необходимость фрундаментальных изменений в подходах к кадастровому учету земель, принятие Закона о реституции по примеру государств, имевших такие же условия развития.

Ключевые слова: децентрализация, административно-территориальная реформа, модернизация экономики, земельная реформа.

The article analyzes the current stage of decentralization reform. The inevitability and fundamental nature of changes, as well as the possibility and expediency of non-standard solutions given the specific conditions of the reform were emphasized. The analysis of the state of reform was carried out in three areas: political, land, social. A list of problems inherent in the current stage of reform in all aspects of the study, provided effective recommendations for the necessary constitutional and legislative regulation, the establishment of relevant institutions and regulatory bodies, streamlining the process of financing local communities, amending the Budget and Tax Codes. Based on the results of opinion polls, the level of public awareness and positive attitude to decentralization reforms was demonstrated. Specific subjective problems that accompanied and were a consequence of the process of administrative unification of communities were identified. Isolated cases of institutional and legal inconsistencies in the powers of various branches of government on the ground have been demonstrated, and appropriate recommendations for their elimination have been provided. The issues of land reform were considered separately in view of the recent legislative changes, which, by the way, were ambiguously perceived by the population. The need for fundamental changes in approaches to land cadastre, the development of mechanisms that would minimize the possibility of land 
speculation, the adoption of the Law on Restitution on the example of states that had the same conditions of development, in particular, the Baltic states. It was emphasized that the reform should be based on the wishes of citizens and the organic formation of OTG, an independent economic and administrative, social basis.

Keywords: decentralization, administrative-territorial reform, modernization of economy, land reform.

Постановка проблеми. Зміни адміністративно-територіального устрою України (далі - АТУ) 32014 року наразі переходять до фрінальної стадії. Процес $€$ незворотнім, тож система місцевої влади в Україні змінюється докорінно. Досвід рефрорм у зарубіжних країнах свідчить, що саме децентралізація $\epsilon$ суттєвим фрактором модернізації економіки, передбачає конкретні кроки 3 покращення якості життя, має чіткі рамки та концептуальне наповнення.

Аналіз останніх досліджень і публікацій. Сучасні українські науковці приділяють достатньо уваги питанням впливу децентралізації на модернізацію економіки України. Наукові аспекти інструментарію модернізації вітчизняної економіки в умовах децентралізації містяться у дослідженнях: О.І. Амоші, В.І. Ляшенка, Ю.С. Залознової, О.Ф. Новікової, Л.М. Саломатіної, Ю.М. Харазішвлі, Н.В. Бутенко, Л.М. Кузьменко, М.О. Солдак та ін.

Виділення невирішених раніше частин загальної проблеми. В той же час, більшість сучасних досліджень, розглядають децентралізаційні процеси секторально - у сенсі суто фрінансової або адміністративної децентралізації. Попри плюралізм поглядів на фрінансову децентралізацію, потребують вирішення питання ефективного додержання балансу у розподілі коштів, спрямованих в результаті децентралізації на розвиток базового рівня та на центральному рівні для забезпечення рішення пріоритетних задач модернізації економіки. Невирішеними є питання розподілу повноважень та бюджетних коштів в умовах нового районування, нагальні питання земельної рефрорми, що й обумовлює актуальність та своєчасність статті.

Формулювання цілей статті. Мета дослідження полягає в аналізі актуального процесу децентралізації, виділенні секторальних успіхів та структурних помилок, наданні рекомендацій для мотивування соціально-економічного розвитку регіонів, «земельної дерегуляції», підвищення ефективності реформи АТУ.

Виклад основного матеріалу дослідження. На сучасному етапі ресрормування в Україні створено на базовому рівні громади, номінально спроможні виконувати всі децентралізовані повноваження, ліквідовано дрібні райони і створено принципово новий субрегіональний рівень 3 населенням від 150 тис. 31 січня 2021 року розпочалось утворення РДА в нових районах. Регіони не підлягали ресрормуванню на цьому етапі.

Зараз є очевидним, що і соціально-економічне ресрормування і технологічна модернізація здійснюються не так швидко, як планувалось, вони стикаються 3 серйозними внутрішніми перешкодами, 3 бюрократичною інерцією та адміністративним консерватизмом, з певним політичним та соціальним спротивом. У суспільстві розгортається гостра дискусія щодо напрямів, змісту та алгоритму здійснення ресрорм.

В той же час, специфічні умови реструктуризації економіки України потребують адекватного нормативного реагування, не виключеними $€$ нестандартні, але необхідні для національних умов рішення. Так, на даний час, Законопроектом № 3651-д, прийнятим 04.12.2020 [1], врегульовуються питання правонаступництва комунального і державного майна, бюджетних ресурсів, прав та зобов'язань, окреслюються питання створення РДА в нових районах. Задля забезпечення роботи, пов'язаної із ліквідацією районів у поточному році, розпорядженням Уряду від 26.01.2021 № 48-р [2] проведено перерозподіл бюджетних коштів в сумі 879 млн грн.

Але, існує низка нагальних для вирішення проблем, яка робить кроки реформування незавершеними та значно знижує мотивацію на місцях. Неофріційно рефрорма АТУ звелася до укрупнення населених пунктів, зменшення адміністративно-територіальних одиниць, передачі на баланс ОМС соціальної ссрери, наприклад, медицини та освіти. Минулорічний Закон України «Про внесення змін до деяких законодавчих актів України щодо умов обігу земель сільськогосподарського призначення» [3] певним чином загострив ситуацію. Так, в умовах вільного обігу землі сільськогосподарського призначення, важливими $€$ питання їх кадастрового обліку, фракт оголошення землі де-юре об'єктом торгівлі, повинен супроводжуватися нормативними актами про реституцію. Необхідним для ресрорми АТУ є перепис населення, який, з низки об'єктивних причин (пандемія, недофрінансування) був перенесений на 2023 рік. 
Практика свідчить, що в тих країнах, де демократичні механізми орормування та реалізації політики працюють, управлення державою та регіонами $\epsilon$ ефективним. В результаті перетворень АТУ, станом на початок 2021 року, нові райони утворюються виключно для організації системи виконавчої влади. Важливо, що рішення про утворення нових та ліквідації (реорганізації) інших державних територіальних органів влади буде відбуватися 3 ініціативи відповідних Центральних органів виконавчої влади (ЦОВВ) за рішенням Уряду протягом 2021 року. Державні послуги, які можна делегувати громадам, надаватимуться через виконкоми громад та Центри надання адміністративних послуг (ЦНАПи).

Позитивним наслідком утворення субрегіонального рівня $\epsilon$ те, що з утворенням великих районів можна позбутися надрайонних утворень, оптимізувати відповідні бюджети. В той же час, відсутність дієвого інструментарію публічного владного управління, провокує можливі кризові явища. Так, зараз децентралізація відбувається без Конституційного офрормлення. Експертами було рекомендовано розпочинати ресрорму саме 3 конституційних змін на основі європейських стандартів [4]. Адже постають питання як конституційної, так і демократичної легітимності. У 2014 році, при затвердженні Концепції децентралізації, не було сформульовано зміст рефрорми виконавчої влади та ОМС, які $є$ абсолютно паралельними спільними діями.

Минулорічна колізія призвела до того, що менше третьої частини адміністративно-територіальних утворень об'єдналися в ОТГ. Інші ж не хотіли об'єднуватися, оскільки не бачили в цьому економічного та соціального сенсу та вбачали певні ризики. Фактично об'єднання територіальних громад відбулося адміністративним шляхом. При цьому було надано право ОДА, їх главам, формувати і подавати КМУ відповідні перспективні плани, або плани регіонального розвитку, попередньо забравши це право у обласних рад. I таким чином адміністративно об'єднати всі майже 90\% територіальних громад, всупереч ст.140 Конституції. Постанова Верховної Ради, якою об'єднали райони [5], і практично вирішили питання АТУ, було прийнято 3 недотриманням ст. 85 і 92 Конституції України, ст. 19 і ст. 8 (Загальні положення) [6]. До того ж замість того, щоб прийняти зміну кількості районів Законом, ВРУ схвалила таке рішення Постановою [5].

В деяких регіонах перебування на посаді глав РДА в середньому становить менше року. Закони «Про добровільне об'єднання територіальних громад» [7], «Про місцеве самоврядування» давали можливість обласним радам формувати перспективні економічні плани регіонального розвитку, та вони й були сформовані за час попередньої влади. Але практично всі плани соціально-економічного розвитку були перероблені за останні місяці, коли укрупнилися громади.

Концепція розвитку місцевого самоврядування і децентралізації влади передбачала демократичні засади, але за об'єктивних причин, процес об'єднання територіальних громад відбувався в умовах відсутності законів про місцевий ресререндум, інших можливостей демократії на місцях. Отже, адміністративний характер проведення об'єднання територіальних громад спричиняє прецеденти щодо добровільності принципів місцевого самоврядування.

Вважаю задоцільне ініціюванняу ВРУ нового конституційного процесу через формування нової Конституційної Асамблеї (далі - КА), 3 широким представництвом вчених НАН України (відповідно до п. 28 ч. 1 ст. $106 \mathrm{Koн-}$ ституції України). Нова КА повинна сорормувати загальний перелік необхідних системних змін, а першим кроком могла б стати випереджальна реформа політичної системи. Існує необхідність створення дорадчого органу фрормату Ради регіонального розвитку, яка функціонувала за попередньої влади, а також, поновити посаду віце-прем'єр-міністра 3 питань децентралізації, до повноважень якого буде входити повноваження впливати на рішення інших міністерств щодо децентралізації.

До соціальної проблематики реформі децентралізації можна додати проведені вибори за партійними списками, що фактично зіграло на руку регіональним елітам тому, що укрупнення районів і вибори за партійними списками в районах більш 10 тис. чол. вдосконалюють місцеві еліти. Загрозливою може стати ситуація, коли, передаючи економічні (фрінансові) зобов'язання на місця, центр фрактично передає і владу на місця. Адже, сьогодні в розумінні населення саме регіональні еліти на 99\% реалізують поняття влади. В таких умовах центральна влада втрачає авторитет на місцях, натомість регіональні еліти підкреслюють свою значимість.

Відповідно до результатів п'ятої хвилі соціологічного дослідження серед населення України, організованого за сприяння Ради Європи [8], оптимістична налаштованість українців до рефрорми зберігається. Цей тренд підживлює 
поінфрормованість громадян. Так, понад 80\% добре поінсормованих респондентів вважають іï потрібною для України. Показово, що цієї думки дотримуються респонденти різних вікових груп. Серед тих, кому 18-29 років, таких майже $60 \%, 30-49$ років $62 \%$.

В той же час, кожен третій українець вважає процес децентралізації ризикованим концентрації влади в руках місцевих еліт. Для населення незрозумілими залишаються економічні питання розподілу фрінансів, які проходять через ОДА.

Формування місцевих ОТГ, які об'єдналися, часто вже не пов'язано з узгодженням інтересів сіл, селищ і міст, які в нього входять. Фактично це утворення агломерацій, де практично все об'єднання громадян відбуваються за принципами соціально-економічної оптимізації обов'язків держави з перекладанням відповідальності та фрінансування на місця. При цьому яким чином фрінансуватимуться і розділятися ці процеси не обговорювалося, що додатково створює підґрунтя для місцевих конфрліктів.

Позитивні приклади, коли фрінанси залишаються на місцях частіше пов'язані $з$ наявністю хорошої інфрраструктури і старих об'єктів, які дають надходження в громади. Власники особливо важливих місцевих об'єктів часто вирішували між собою до якої громаді їм краще приєднатися, задля можливості впливу на владу. В той же час реформа повинна базуватися на бажаннях громадян і органічному фрормуванні ОТГ, незалежному економічному та адміністративному, соціальному базисі.

Шляхом прийняття відповідних змін до Бюджетного та Податкового кодексів, відповідних Законів слід надати місцевим органам самоврядування можливість самостійно і незалежно заробляти гроші. В більшій мірі їм потрібно передати: податкову базу (можливо, повністю), можливість створення спеціальних економічних і податкових регулювань в регіоні, розширені соціальні і адміністративні права для того, щоб ОМС зумовлювали свою соціально-економічну політику у своїх регіонах. Таким чином можна мотивувати регіональні еліти розвивати території, а населення - вкладати гроші у свої регіони. Задля перешкоджання перетворення пресректа на «генерал-прокурора», в українських регіонах необхідно створювати автономні, життєздатні та окремі моделі за прикладом закордонних.

На нашу думку, існує перелік концептуальних засади змін до Бюджетного (БКУ) та Податкового кодексу України. А саме: зі структури місцевих бюджетів виключити суб'єкт «ОТГ»; бюджетами місцевого самоврядування визначити бюджети міських, селищних, сільських територіальних громад; розмежувати: видатки сільських, селищних, міських, районних та обласних бюджетів на власні і делеговані; дохідні та видаткові повноваження за принципом субсидіарності; скасувати спрямування надходжень від ПДФО до районних бюджетів; виключити з БКУ поняття «зведений бюджет району» і цим підсилити самостійність бюджетів місцевого самоврядування.

Щодо одного з найважливіших економічних ресурсів країни - землі - зазначимо наступне. Історично для українців земля - це не просто ресурс чи товар. Минулий рік позначився зміною кон'юнктури у підходах до обігу землі та прийняттям відповідного Закону [3], який був вкрай неоднозначно прийнятий українцями. Проте, ринок земель сільгосппризначення приватної фрорми власності в Україні діє досить давно. «Торгівля» розпайованими землями здійснюється через різні договірні конструкції (довгострокова оренда, емфрітевзис, міна, дарування, іпотека, заповіт тощо). Зняття заборони на відчуження земель не запустить ринок землі, адже неможливо запустити те, що вже працює (хоч і неофріційно). Але, законне скасування такого табу дає змогу вивести поточний ринок землі 3 напівлегальної площини в законну.

В той же час, не ухвалено Закону про реституцію. Але ж одна із базових засад ЄС повага до приватної власності, як це зробили Латвія, Естонія, Литва. Подібна проблема $\epsilon$ спільною для всіх «перехідних країн», де земля була націоналізована або її обіг жорстко контролювався. На жаль, більшість селян досі не приватизували власні садиби, через віддаленість центрів адміністративних послуг від сіл, недостатню кількість обслуговуючого персоналу, юристів, нотаріусів, значну вартість процедури.

Сьогодні ОТГ фрактично не мають законних підстав отримати землі несільськогосподарського призначення за межами населених пунктів у комунальну власність, що не відповідає самому концепту децентралізації та зменшує спроможність громад до економічного розвитку. Це може вирішити ухвалення законопроекту «Про внесення змін до Земельного кодексу України та інших законодавчих актів щодо удосконалення системи управління та дерегуляції у сорері земельних відносин» № 2194 [9], який знаходиться на доопрацюванні у ВРУ. 
Необхідно законодавчо визначитися з відновленням соціально-економічної справедливості в ссрері обігу землі. Для цього: законодавчим органам розробити та прийняти блок Законів про земельну детінізацію, відпрацювати механізми, які б звели до мінімуму можливість спекуляції землею; органам центральної влади унеможливити зосередження в приватній власності земель сільськогосподарського призначення, площа яких перевищуватиме встановлені законом обсяги; установити невідворотність покарання учасників ринку за порушення визначених правил. Органам державного земельного кадастру провести повний аудит поточного стану землекористування, здійснити стовідсоткове наповнення земельного кадастру інформацією про сільгоспземлі, завершити процес оцифрування території країни на предмет обліку земельних ділянок.

Висновки. Отже, процес децентралізації повинен бути тісно пов'язаний з новою економічною парадигмою трансорормації всієї регіональної економічної структури, мати спрямування на модернізацію економіки, забезпечувати соціальну легітимність та справедливість.

Розрив, який буде здійснений на новому регіональному рівні, може сприяти стихійному волевиявленню. Передача економічних ресурсів на рівень ОТГ фрактично відбулася і нові райони вже можуть захищати свої інтереси аж до перегляду рішень держави, таким чином повноцінно впливаючи на власний розвиток. Існує необхідність нового конституційного процесу на неконфрліктній основі.

\section{СПИСОК ВИКОРИСТАНИХ ДЖЕРЕЛ:}

1. Про внесення змін до деяких законів України щодо впорядкування окремих питань організації та діяльності органів місцевого самоврядування і районних державних адміністрацій : Закон України від 17.11.2020 № 1009-ІХ. Голос України від 05.12.2020 № 226.

2. Про розподіл частини бюджетних призначень, передбачених у 2021 році за програмою забезпечення окремих видатків районних державних адміністрацій, пов'язаних з ліквідацією районів : Розпорядження КМУ від 26.01.2021 № 48-p. База даних «Законодавство України». URL: https://www.kmu.gov.ua/npas/pro-rozpodilchastini-byudzhetnih-pri-a48r (дата звернення: 09.03.2021).

3. Про внесення змін до деяких законодавчих актів України щодо умов обігу земель сільськогосподарського призначення : Закон України від 31.03.2020 № 552-ІХ. Голос України від 30.04.2020 №№ 74-75.

4. Український Інститут політики. Офіційний сайт. URL: https://uiamp.org.ua/decentralizaciya-kak-elementkonstitucionnyh-izmeneniy-sostoyanie-razvitiya-mestnogo-samoupravleniya (дата звернення: 09.03.2021).

5. Про утворення та ліквідацію районів : Постанова Верховної Ради України від 17.07.2020 № 807-ІХ. Голос України від 18.07.2020 № 122.

6. Конституція України : Закон України від 28.06.1996 № 254к/96-ВР. Верховна Рада України. URL: http://zakon2.rada.gov.ua/aws/show/254к/96-вр (дата звернення: 09.03.2021).

7. Про добровільне об'єднання територіальних громад : Закон України від 05.02.2015 № 157-VIII. Відомості Верховної Ради України від 27.03.2015 - 2015 р., № 13, стор. 734, стаття 91.

8. Децентралізація та реформа місцевого самоврядування. Результати п'ятої хвилі соціологічного дослідження серед населення України. Аналітичний звіm. URL: http://www.slg-coe.org.ua/wp-content/ uploads/2020/11/2020Report_UKR_ukr_1.pdf (дата звернення: 09.03.2021) .

9. Про внесення змін до Земельного кодексу України та інших законодавчих актів щодо удосконалення системи управління та дерегуляції у ссрері земельних відносин : Проект Закону від 01.10.2019 № 2194. База даних «Законодавство України». URL: http://w1.c1.rada.gov.ua/pls/zweb2/webproc4_1?pf3511=66970 (дата звернення: 09.03.2021).

\section{REFERENCES:}

1. Pro vnesennya zmin do deyakyx zakoniv Ukrayiny shhodo vporyadkuvannya okremyx pytan organizaciyi ta diyalnosti organiv miscevogo samovryaduvannya i rajonnyx derzhavnyx administracij: Zakon Ukrayiny vid 17.11.2020 № 1009-IX [On Amendments to Certain Laws of Ukraine Concerning the Regulation of Certain Issues of Organization and Activity of Local Self-Government Bodies and District State Administrations: Law of Ukraine]. Golos Ukrayiny vid 05.12.2020 no. 226 (in Ukrainian)

2. Pro rozpodil chastyny byudzhetnyx pryznachen, peredbachenyx u 2021 roci za programoyu zabezpechennya okremyx vydatkiv rajonnyx derzhavnyx administracij, pov'yazanyx z likvidaciyeyu rajoniv: Rozporyadzhennya KMU vid 26.01.2021 № 48-r [Resolution of CMU dated 26.01.2021 № 48-к About distribution of a part of the budgetary 
appointments provided in 2021 under the program of maintenance of separate expenses of the district state administrations connected with liquidation of areas]. Baza danyx «Zakonodavstvo Ukrayiny». URL: https://www.kmu.gov.ua/ npas/pro-rozpodil-chastini-byudzhetnih-pri-a48r (in Ukrainian)

3. Pro vnesennya zmin do deyakyx zakonodavchyx aktiv Ukrayiny shhodo umov obigu zemel silskogospodarskogo pryznachennya: Zakon Ukrayiny vid 31.03.2020 № 552-IX [On Amendments to Certain Legislative Acts of Ukraine Concerning the Conditions of Circulation of Agricultural Lands: Law of Ukraine of March 31, 2020 № 552-IX]. Golos Ukrayiny vid 30.04.2020 №№ 74-75. (in Ukrainian)

4. Ukrayinskyj Instytut polityky. Oficijnyj sajt. [Ukrainian Institute of Politics]. URL: https://uiamp.org.ua/decentralizaciya-kak-element-konstitucionnyh-izmeneniy-sostoyanie-razvitiya-mestnogo-samoupravleniya (in Ukrainian)

5. Pro utvorennya ta likvidaciyu rajoniv: Postanova Verxovnoyi Rady Ukrayiny vid 17.07.2020 № 807-IX [On the formation and liquidation of districts: Resolution of the Verkhovna Rada of Ukraine of 17.07.2020 № 807-IX]. Golos Ukrayiny vid 18.07 .2020 no. 122. (in Ukrainian)

6. Konstytutsiia Ukrainy: Zakon Ukrainy vid 28.06.1996 № 254k/96-VR. Vidomosti Verkhovnoi Rady Ukrainy (VVR), 1996, № 30, st. 141 (in Ukrainian)

7. Pro dobrovilne ob'yednannya terytorialnyx gromad: Zakon Ukrayiny vid 05.02.2015 № 157-VIII [On voluntary association of territorial communities: Law of Ukraine of 05.02.2015 № 157-VIII]. Vidomosti Verxovnoyi Rady Ukrayiny vid 27.03.2015 - 2015 r., no. 13, stor. 734, stattya 91. (in Ukrainian)

8. Decentralizaciya ta reforma miscevogo samovryaduvannya. Rezultaty p'yatoyi xvyli sociologichnogo doslidzhennya sered naselennya Ukrayiny. Analitychnyj zvit. URL: http://www.slg-coe.org.ua/wp-content/uploads/ 2020/11/2020Report_UKR_ukr_1.pdf (in Ukrainian)

9. Pro vnesennya zmin do Zemelnogo kodeksu Ukrayiny ta inshyx zakonodavchyx aktiv shhodo udoskonalennya systemy upravlinnya ta deregulyaciyi u sferi zemelnyx vidnosyn: Proekt Zakonu vid 01.10.2019 № 2194 [On Amendments to the Land Code of Ukraine and Other Legislative Acts on Improving the System of Management and Deregulation in the Sphere of Land Relations: Draft Law of October 1, 2019 № 2194]. Baza danyx «Zakonodavstvo Ukrayiny». URL: http://w1.c1.rada.gov.ua/pls/zweb2/webproc4_1?pf3511=66970 (in Ukrainian) 